\title{
Pengaruh Pemberian Virgin Coconut Oil (VCO) dan Olive Oil terhadap Mikroanatomi Ren Tikus Putih (Rattus norvegicus)
}

\author{
Riani Nurasri, Enny Yusuf W.Y dan M. Anwar Djaelani \\ Laboratorium Biologi Struktur dan Fungsi Hewan, Departemen Biologi, Fakultas Sains dan Matematika, \\ Universitas Diponegoro Jl. Prof. H. Sudharto, Tembalang, Semarang.
}

\begin{abstract}
Virgin Coconut Oil (VCO) and olive oil have been widely applied in the field of health. Saturated fatty acid content of VCO dominates the total fatty acid content of about $85 \%$. Olive oil contains a lot of oleic acid, which is one type of unsaturated fatty acid (mono-unsaturated fatty acid). This study aimed to analyze the kidney microanatomy rat (Rattus norvegicus) after supplementation with VCO and olive oil in the feed. This study used 25 rats were divided into five treatment groups, P1 was the control group, P2 was a group with VCO $5 \mathrm{~mL} / \mathrm{kg}$ feed, P3 was a group with VCO $10 \mathrm{~mL} / \mathrm{kg}$ of feed, $\mathrm{P} 4$ was a group with olive oil $5 \mathrm{~mL} / \mathrm{kg}$ feed and was a group with olive oil $10 \mathrm{~mL} / \mathrm{kg}$ of feed. The results of ren weight and diameter rat glomerular analyzed using analysis of variance (ANOVA). Research design used was completely randomized design with five treatments and five replication. Results of studies on weight ren showed no significant difference between treatments P2, P3, P4 and P5 to the control (P1). The results of the glomerular diameter shows there is significantly difference between the diameter of the glomerulous treatment P2 and P3 with control (P1), while in treatment P4 and P5 are not significantly different from the control so that it can be concluded that the administration of the VCO and olive oil at various concentrations do not give rise to different responses to weight ren. Olive oil does not increases glomerular diameter white mice, while VCO at a dose of $5 \mathrm{~mL} / \mathrm{kg}$ feed and $10 \mathrm{~mL} / \mathrm{kg}$ of feed can increased glomerular diameter mice.
\end{abstract}

Keywords: ren weight, glomerular diameter, Virgin Coconut Oil (VCO), olive oil.

\begin{abstract}
Abstrak
Virgin Coconut Oil ( $\mathrm{VCO})$ dan olive oil telah banyak diaplikasikan dalam bidang kesehatan. Kandungan asam lemak jenuh VCO mendominasi terhadap kandungan asam lemak total sekitar $85 \%$. Olive oil banyak mengandung asam oleat yang merupakan salah satu jenis asam lemak tak jenuh (mono unsaturated fatty acid). Penelitian ini bertujuan untuk menganalisis mikroanatomi ginjal tikus putih (Rattus norvegicus) setelah pemberian suplemen (VCO) dan olive oil pada pakan. Penelitian ini menggunakan 25 ekor tikus putih yang dibagi dalam lima kelompok perlakuan, yaitu P1 adalah kelompok kontrol, P2 merupakan kelompok yang diberi $V C O 5 \mathrm{~mL} / \mathrm{kg}$ pakan, P3 merupakan kelompok yang diberi VCO $10 \mathrm{~mL} / \mathrm{kg}$ pakan, P4 merupakan kelompok yang diberi olive oil $5 \mathrm{~mL} / \mathrm{kg}$ pakan dan P5 merupakan kelompok yang diberi olive oil $10 \mathrm{~mL} / \mathrm{kg}$ pakan. Hasil data pengamatan berat ren dan diameter glomerulus tikus dianalisis menggunakan analisis of varians (ANOVA). design penelitian yang digunakan adalah rancangan acak lengkap dengan lima perlakuan dan lima ulangan. Hasil penelitian berat ren menunjukkan tidak terdapat beda nyata antara perlakuan P2, P3, P4 dan P5 terhadap kontrol (P1). Hasil yang didapat mengenai diameter glomerulus menunjukkan terdapat beda nyata antara diameter glomerulus perlakuan P2 dan P3 dengan kontrol (P1), sedangkan pada perlakuan P4 dan P5 tidak berbeda nyata terhadap kontrol sehingga dapat disimpulkan bahwa pemberian VCO dan olive oil pada berbagai konsentrasi tidak menimbulkan perbedaan respon terhadap berat ren. Olive oil tidak menimbulkan peningkatan diameter glomerulus tikus putih, sedangkan pemberian VCO pada dosis $5 \mathrm{~mL} / \mathrm{kg}$ pakan dan $10 \mathrm{~mL} / \mathrm{kg}$ pakan menimbulkan peningkatan diameter glomerulus tikus putih.
\end{abstract}

Kata kunci: berat ren, diameter glomerulus, Virgin Coconut Oil (VCO), olive oil.

\section{PENDAHULUAN}

Virgin Coconut Oil (VCO) dikenal memiliki berbagai manfaat dalam bidang kesehatan maupun kebugaran tubuh. VCO memiliki warna jernih serta aroma dan rasa yang khas (Kamariah et al., 2008). Edahwati (2011) menyatakan bahwa 
kandungan asam lemak jenuh pada VCO mendominasi sebesar $85 \%$ dari kandungan asam lemak total. Asam lemak rantai sedang yaitu asam laurat serta pada VCO tidak mengandung ikatan trans dan tidak membentuk radikal bebas. Hasil penelitian secara in vitro menunjukan asam lemak rantai sedang memiliki manfaat sebagai anti jamur, anti bakteri, anti virus dan dapat membunuh patogen pada manusia seperti herpes simplex virus dan anti protozoa (Kamariah et al., 2008). Pemberian VCO dan olive oil dosis $5 \mathrm{~mL} / \mathrm{kg}$ pakan dan $10 \mathrm{~mL} / \mathrm{kg}$ pakan tidak menimbulkan perbedaan respon kadar trigliserid tikus putih (Yuniwarti, 2015).

Olive Oil merupakan minyak yang diperoleh dari hasil pemerasan buah zaitun (Oleum europa). Olive oil dikenal baik bagi kesehatan karena banyak mengandung asam lemak tak jenuh. Olive oil kaya akan asam oleat dan MUFA (Monounsatturated fatty acid) yang tidak mudah teroksidasi dan bersifat stabil. Berdasarkan hasil penelitian diketahui asam lemak tak jenuh pada olive oil dapat mengurangi resiko penyakit kardiovaskular dan kanker. Komponen bioaktif yang terkandung pada olive oil meliputi hidrokarbon, senyawa sterol, polifenol, tokoferol, terpenoid dapat berperan sebagai anti inflamasi, antioksidan, antiarrthytmic, dan vasodilatory effect (Covas, 2006; Remirez, 2006).

Ginjal merupakan organ ekskresi utama pada vertebrata yang berfungsi untuk menyaring sisa hasil metabolisme dari darah serta mengatur keseimbangan asam dan basa dalam tubuh (Guyton, 2007). Unit terkecil ginjal yang dapat menghasilkan urin disebut nefron. Nefron tersusun oleh glomerulus, kapsula bowman, tubulus kontortus proksimal, tubulus kontortus distal (Junquierra et al., 2007). Berdasarkan berbagai penelitian diketahui bahwa penyakit ginjal kronis dapat disebabkan oleh penimbunan lemak pada jaringan non adiposa seperti ginjal. Akumulasi lemak pada jaringan ginjal menyebabkan perubahan struktur glomerulus dan terjadinya peradangan (inflamasi) pada tubulus interstisial (Eghziabher et al., 2013).

Akumulasi lemak pada jaringan ginjal berkontribusi pada peningkatan resiko kerusakan glomerulus dan tubulus interstisial, chronic glumeropathy, nephrotic syndrome, dan diabetic nephrophathy serta atherosklerosis (Kim et al., 2009). Glomerulosklerosis merupakan proses sklerosis glomeruli yang progresif karena kerusakan sel intra-glomerular baik pada sel glomerulus intrinsik yaitu: endotel, sel mesangium, dan sel epitel maupun sel ekstrinsik yaitu: trombosit, limfosit, monosit/makrofag (Fogo, 2000). Faktor yang berperan dalam terjadinya glomerulosklerosis antara lain menurunnya kemampuan autoregulasi glomerular, tekanan intra glomerular, iskemik glomerular, serta peran angiotensin II (Firmansyah, 2013). Hasil Penelitian Witradharma dkk. (2010) tentang pengaruh konsumsi berbagai jenis asam lemak terhadap indikator kejadian aterogenesis pada tikus putih menunjukkan bahwa tikus putih yang diberi VCO pada pakan memiliki rerata kolesterol total paling tinggi dibanding dengan penambahan olive oil dan minyak jagung. Berdasarkan uraian diatas, maka perlu diteliti lebih lanjut mengenai pengaruh VCO dan Olive oil terhadap mikroanatomi ginjal tikus putih (Rattus norvegicus)

\section{BAHAN DAN METODE}

Sebanyak 25 ekor tikus putih Strain Wistar jantan umur satu bulan dipergunakan sebagai hewan uji. Tikus putih diaklimasi selama satu minggu. Hewan coba diberi makanan standar dan minum setiap hari secara ad libitum, serta ditimbang kemudian dikelompokan secara acak. Tikus putih dibagi menjadi lima kelompok, masing-masing kelompok terdiri dari lima ekor. Kelompok P1 adalah kelompok kontrol, yaitu tikus putih yang diberi pakan tanpa penambahan VCO dan olive oil. Kelompok P2 adalah kelompok tikus putih yang diberi VCO $5 \mathrm{ml} / \mathrm{kg}$ pakan. Kelompok P3 adalah kelompok tikus putih yang diberi VCO $10 \mathrm{ml} / \mathrm{kg}$ pakan. Kelompok P4 adalah kelompok tikus putih yang diberi olive oil $5 \mathrm{ml} / \mathrm{kg}$ pakan. Kelompok P5 adalah kelompok tikus putih yang diberi olive oil $10 \mathrm{ml} / \mathrm{kg}$ pakan. Tikus putih dibedah untuk diambil organ ginjalnya pada akhir penelitian. Organ ginjal yang digunakan adalah ginjal sebelah kiri (sinister). Pembedahan dan pengambilan organ dilakukan menggunakan alatalat bedah. Organ ginjal selanjutnya ditimbang dan dicuci dengan garam fisiologis dan dimasukan kedalam botol berisi BNF untuk proses pengawetan dan fiksasi. 


\section{Pembuatan Preparat Mikronatomi Ren}

Pembuatan preparat histopatologi dilakukan dengan cara organ ginjal dicuci menggunakan alkohol $70 \%$ hingga alkohol berwarna jernih, selanjutnya organ ginjal difiksasi dengan menggunakan larutan BNF $10 \%$ kemudian dipotong dan dimasukkan ke dalam tempat spesimen yang terbuat dari plastik. Proses dehidrasi menggunakan alkohol konsentrasi bertingkat yaitu alkohol $70 \%, 80 \%, 90 \%$ alkohol absolut I, absolut II masing-masing 30 menit. Cairan dehidran kemudian dibersihkan dari dalam jaringan dengan menggunakan reagen pembersih (clearing agent) yaitu xylol. Penjernihan dengan xylol dengan perbandingan alkohol: xylol 3:1, 1:1, 1:3 masing-masing selama 30 menit. Tahapan selanjutnya adalah infiltrasi parafin, paraffin yang digunakan mempunyai titik cair $56-58^{\circ} \mathrm{C}$. kemudian organ dicetak menggunakan parafin cair. Blok-blok parafin disimpan dalam lemari es. Blok paraffin tersebut kemudian dipotong tipis setebal lima $m$ menggunakan mikrotom. Hasil potongan diapungkan dalam air hangat bersuhu $60^{\circ} \mathrm{C}$ untuk meregangkan agar jaringan tidak berlipat. Sediaan kemudian diangkat dan diletakkan dalam gelas objek untuk dilakukan pewarnaan Hematoxylin dan Eosin (HE), kemudian dilakukan mounting dengan meneteskan entelan secukupnya dan ditutup dengan cover glass. Selanjutnya diperiksa dibawah mikroskop (Suhita dkk., 2013).

\section{Pengamatan Preparat Mikroanatomi Ren}

Pengamatan preparat dilakukan menggunakan mikroskop perbesaran 10x10 kali. Setiap preparat diamati tiga bidang pandang, dari setiap bidang pandang diambil lima glomerulus. Diameter glomerulus yang didapat merupakan rata-rata dari pengukuran diameter setiap glomerulus secara vertikal dan horizontal.

\section{Analisis Data}

Data berat dan diameter glumerolus yang didapat dianalisis dengan menggunakan uji ANOVA dengan taraf signifikansi 5\%. Data diameter glomerulus dianalisis menggunakan uji lanjut dengan uji DUNCAN (DMRT). Perhitungan menggunakan perangkat lunak program SPSS versi 16 (Santoso, 2010).

\section{HASIL DAN PEMBAHASAN}

Hasil analisis rata-rata dari berat ren dan diameter glomerulus dari penelitian pengaruh VCO dan olive oil terhadap mikroanatomi ren tikus putih (Rattus norvegicus) disajikan pada Tabel 1

Tabel 1. Hasil analisis rata-rata berat ren dan diameter glomerulus tikus putih (Rattus norvegicus) setelah penambahan VCO dan olive oil pada pakan.

\begin{tabular}{llllll}
\hline Variabel Ukur & \multicolumn{5}{c}{ Perlakuan } \\
\cline { 2 - 6 } & \multicolumn{1}{c}{ P1 } & \multicolumn{1}{c}{ P2 } & \multicolumn{1}{c}{ P3 } & \multicolumn{1}{c}{ P4 } & \multicolumn{1}{c}{ P5 } \\
Berat ren (gram) & $0,866^{\mathrm{a}} \pm 0,16$ & $0,856^{\mathrm{a}} \pm 0,12$ & $0,896^{\mathrm{a}} \pm 0,1$ & $0,816^{\mathrm{a}} \pm 0,12$ & $0,908^{\mathrm{a}} \pm 0,12$ \\
& & & & & \\
Diameter & $244,064^{\mathrm{a}}$ & $269,672^{\mathrm{b}}$ & $265,530^{\mathrm{b}}$ & $256,086^{\mathrm{ab}} \pm$ & $248.015^{\mathrm{a}}$ \\
glomerulus ren & $\pm 6,9$ & $\pm 5,8$ & $\pm 9,6$ & 9,1 & $\pm 4,4$ \\
$(\mathrm{~m})$ & & & & & \\
\hline
\end{tabular}

Keterangan: Angka yang ditunjukan dengan superskrip yang sama pada baris yang sama menunjukkan perbedaan tidak nyata $(\mathrm{P}>0,05) . \mathrm{P} 1$ : kelompok kontrol, $\mathrm{P} 2$ kelompok yang diberi $\mathrm{VCO} 5 \mathrm{~mL} / \mathrm{kg}$ pakan, P3: kelompok yang diberi VCO $10 \mathrm{~mL} / \mathrm{kg}$ pakan, P4: kelompok yang diberi Olive Oil $5 \mathrm{~mL} / \mathrm{kg}$ pakan dan P5: kelompok yang diberi Olive Oil $10 \mathrm{~mL} / \mathrm{kg}$ pakan.

Data berat ren setelah dianalisis menggunakan Analysis of Variance (ANOVA) menunjukkan bahwa berat ren tikus putih kontrol maupun perlakuan, baik yang menggunakan VCO maupun olive oil pada dosis 5 dan $10 \mathrm{~mL} / \mathrm{kg}$ pakan berbeda tidak nyata $(\mathrm{P}>0,05)$. Hal tersebut menunjukkan bahwa VCO maupun olive oil tidak berpengaruh terhadap berat ren tikus putih (Rattus 
norvegicus). Berat ren tikus putih yang tidak berbeda nyata pada semua kelompok perlakuan menunjukkan bahwa pemberian $\mathrm{VCO}$ dan olive oil pada dosis 5 dan $10 \mathrm{~mL} / \mathrm{kg}$ pakan tidak menimbulkan penambahan massa organ.

Berdasarkan hasil analisis data menunjukkan bahwa diameter glomerulus tikus putih kontrol maupun perlakuan, baik yang menggunakan VCO pada dosis 5 dan $10 \mathrm{~mL} / \mathrm{kg}$ pakan menunjukkan hasil yang berbeda nyata setelah dianalisis menggunakan Analysis of Variance (ANOVA) dan uji BNT taraf 5\% $(\mathrm{p}<0,05)$. Hasil analisis data diameter glomerulus menggunakan uji Duncan (Tabel 4.1) menunjukkan adanya perbedaan nyata pada beberapa perlakuan yaitu kelompok perlakuan P2 dan P3 terhadap perlakuan P1 (kontrol) ditandai dengan peningkatan signifikan diameter glomerulus pada dua kelompok perlakuan (P2 dan P3) dibandingkan kelompok kontrol (P1). Kelompok P4 dan P5 menunjukkan hasil berbeda tidak nyata terhadap P1. Peningkatan ukuran diameter glomerulus dimungkinkan merupakan salah satu gejala awal terjadinya kerusakan sel. Glomerulus merupakan kapiler komplek yang mempunyai fungsi utama dalam filtrasi. Apabila terjadi kerusakan pada glomerulus maka daya filtrasi akan terganggu (Sulistyowati dkk., 2013)



Gambar 1. Glomerulus ren tikus putih perlakuan kontrol. A: Glomerulus

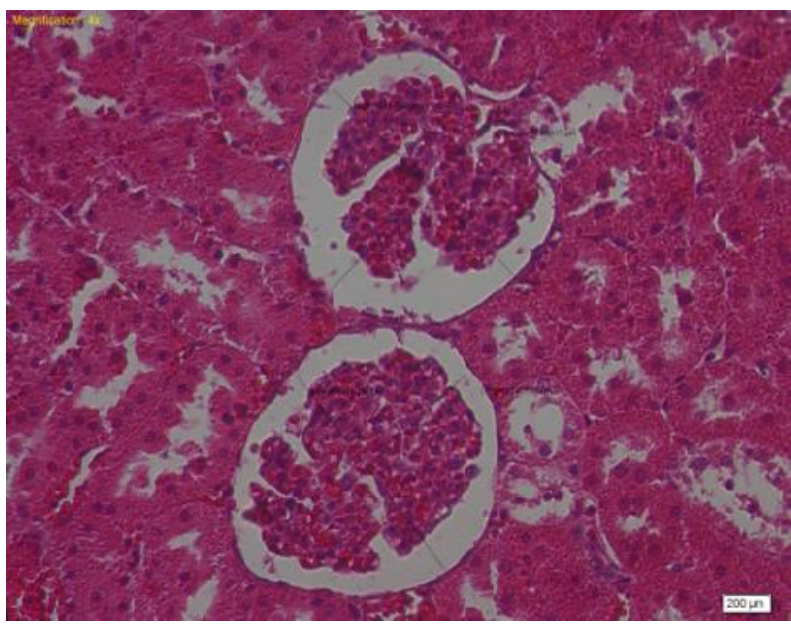

Gambar 2. Glomerulus ren tikus putih setelah perlakuan pemberian $\mathrm{VCO} 5 \mathrm{ml} / \mathrm{kg}$ pakan. A: Glomerulus

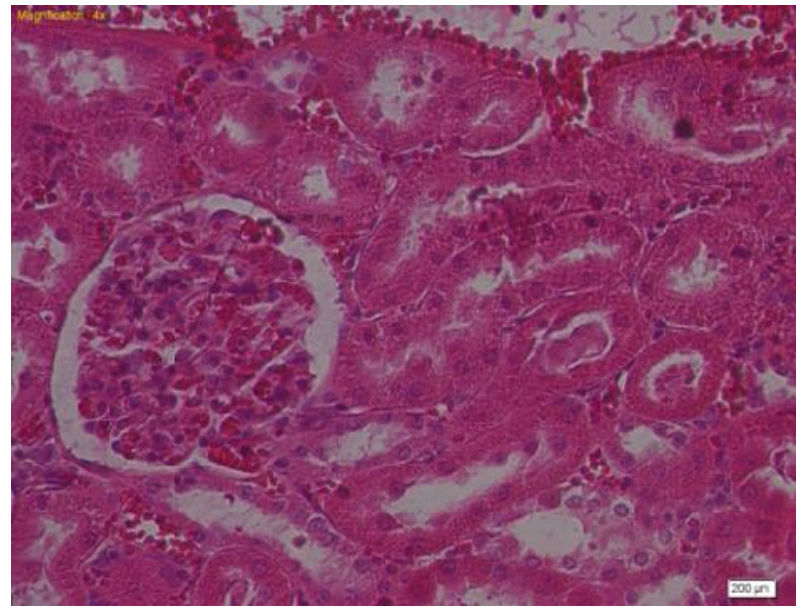

Gambar 3. Glomerulus ren tikus putih setelah perlakuan pemberian $\mathrm{VCO} 10 \mathrm{ml} / \mathrm{kg}$ pakan. A: Glomerulus 


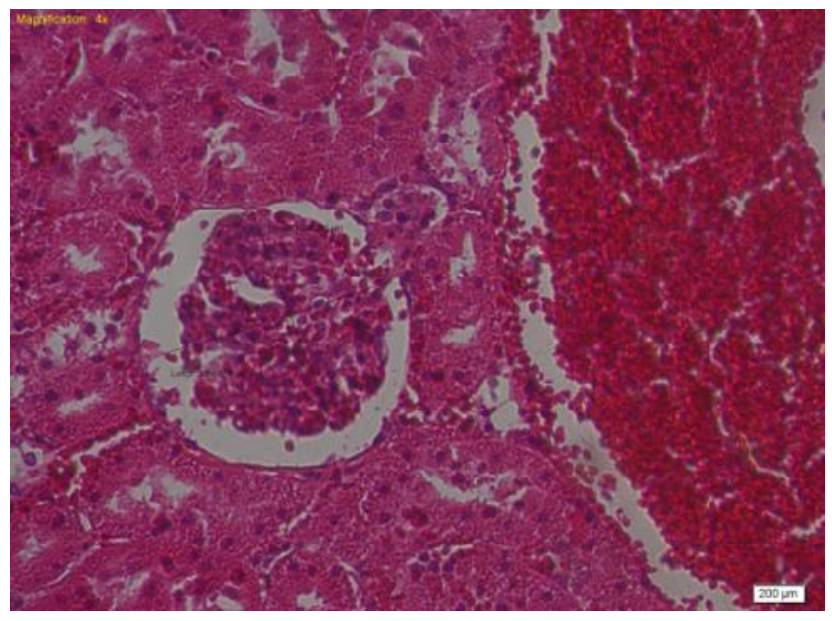

Gambar 4. Glomerulus ren tikus putih setelah perlakuan pemberian olive oil $5 \mathrm{ml} / \mathrm{kg}$ pakan. A: Glomerulus

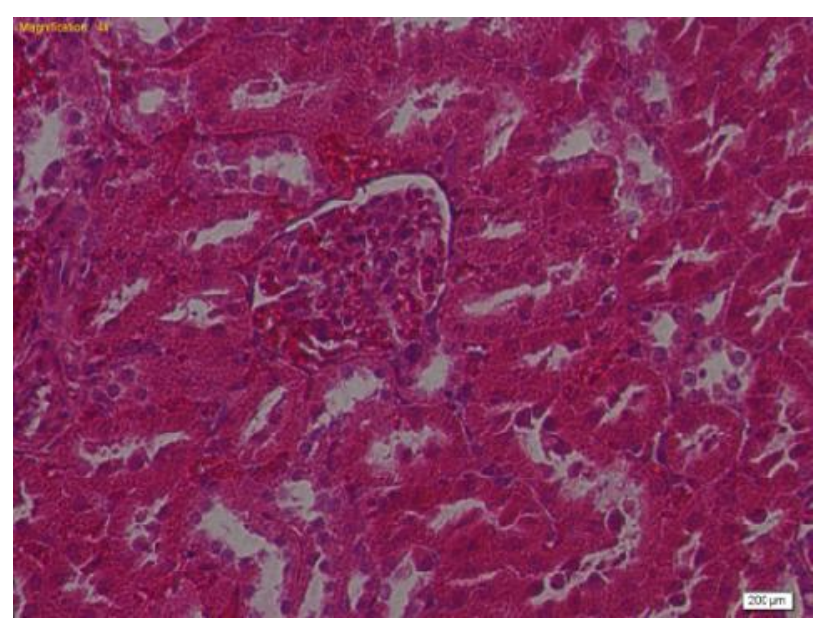

Gambar 5. Glomerulus ren tikus putih setelah perlakuan pemberian olive oil $10 \mathrm{ml} / \mathrm{kg}$ pakan. A: Glomerulus

Peningkatan diameter glomerulus pada perlakuan pemberian VCO $5 \mathrm{~mL} / \mathrm{kg}$ pakan dan 10 $\mathrm{mL} / \mathrm{kg}$ pakan dibandingkan perlakuan kontrol diduga disebabkan karena VCO pada dosis tersebut menimbulkan kerusakan pada sel ginjal yang ditandai dengan terjadinya pembengkakan pada glomerulus meskipun belum sampai mempengaruhi perubahan massa organ ginjal. Hal tersebut dikarenakan glomerulus merupakan bagian atau segmen awal dari nefron dan bukan komponen terbesar penyusun nefron. Junquierra $e t$ al. (2007) menyatakan bahwa nefron merupakan komponen penyusun utama ren yang terdiri atas glomerulus dan tubulus. Tubulus pada ren terdiri dari tubulus kontortus proksimal, lengkung henle, tubulus kontortus distal dan duktus kolingentes. Tubulus merupakan saluran panjang berkelokkelok dan dikelilingi pembuluh darah kapiler.

Kandungan asam lemak jenuh pada VCO menurunkan reseptor LDL yang berhubungan dengan katabolisme serta meningkatkan formasi LDL plasma dengan menurunkan efek turn over $L D L$ kolesterol sehingga meningkatkan kadar $L D L$ (Witradharma dkk., 2010). Low Density Lipoprotein $(L D L)$ merupakan mediator dalam pembentukan sel busa pada proses terjadinya aterosklerosis (Viola dan Soehnlein, 2015). Low Density Lipoprotein berasal dari lipoprotein berdensitas sedang yang sebagian besar trigliseridnya sudah dikeluarkan sehingga menyebabkan konsentrasi kolesterol dan fosfolipid tinggi (Mayer, 2003).

Kolesterol dalam tubuh yang melebihi batas normal (Hiperkolestrolemia) merupakan faktor resiko yang dapat menyebabkan terbentukn $\cdots \cdots \mathrm{k}$ aterosklerosis (Tambunan dkk., _...t). Hiperkolesterolemia juga cenderung mengakibatkan oksidasi LDL melalui peningkatan substrat, perubahan konformasi LDL yang lebih rentan terhadap oksidasi sehingga berdampak buruk pada sel endotel (Smith et al., 2005).

Lesi aterosklerotik diawali oleh ya kerusakan sel-sel endotel pembuluh darah.. Endotel bersifat antitrombogenik, yang mencegah pembekuan darah. Apabila se-sel endotel rusak maka jaringan ikat yang terpapar akan menginduksi penggumpalan trombosit darah. Penggumpalan trombosit mengawali sederet kejadian yang menghasilkan fibrin dan fibrinogen darah yang kemudian membentuk bekuan intravaskuler atau trombus (Isdadiyanto, 2015). Diet asam lemak diduga akan mengakibatkan disfungsi sel-sel endothelia yang merupakan kejadian paling awal aterosklerosis (Yanuartono, 2007).

Fibrinogen merupakan molekul protein utama pada sistem pembekuan darah. Konsentrasi fibrinogen yang tinggi dapat menyebabkan agregasi eritrosit yang bersirkulasi sehingga menyebabkan peningkatan viskositas darah 
(Turgeon, 2010). Guyton dan Hall (2007), menyatakan bahwa semakin besar viskositas darah, aliran dalam pembuluh darah semakin kecil. Akibatnya dapat terjadi peningkatan resistensi pembuluh darah, gangguan sirkulasi oksigen dalam darah dan akhirnya timbul penyumbatan atau pecahnya pembuluh darah. Peningkatan viskositas darah pada populasi menjadi prediktor kejadian penyakit kardiovaskular karena viskositas darah mempengaruhi hipertensi (Kesmarky et al., 2008). Viskositas darah yang tinggi dapat meningkatkan resistensi perifer yang berdampak pada berkurangnya laju aliran darah. Apabila resistensi meningkat maka gradien tekanan harus meningkat secara proporsional agar laju aliran darah tetap. Kondisi abnormalitas hemodinamik yang ekstrim dapat menyebabkan pelebaran pembuluh darah kapiler yang menyebabkan peningkatan ukuran glomerulus (Fogo, 2000). Perubahan hemodinamika lokal pada glomerulus seperti peningkatan tekanan di glomerulus dapat menyebabkan pelebaran ukuran glomerulus dan glomerulosklerosis. Peningkatan ukuran glomerulus (glomerular hypertrophy) memiliki kaitan dengan penyakit glomerusklerosis pada manusia maupun hewan model. Peningkatan ukuran glomerulus dapat pula disebabkan karena adanya peningkatan ukuran dan jumlah sel mesangial serta sel epitel visceral glomerulus (Fogo, 2000).

Diameter glomerulus pada perlakuan penambahan olive oil dengan dosis $5 \mathrm{~mL} / \mathrm{kg}$ pakan (P4) yaitu 260,686 $\mu \mathrm{m}$ dan $10 \mathrm{~mL} / \mathrm{kg}$ pakan (P5) yaitu $250,415 \mu \mathrm{m}$ menunjukkan perbedaan tidak nyata terhadap diameter glomerulus kelompok kontrol yaitu 244,063 $\mu \mathrm{m}$. Hal tersebut menunjukkan bahwa penggunaan olive oil pada pakan tidak menimbulkan perubahan signifikan terhadap diameter glomerulus. Menurut Kano et al., (2006) olive oil mengandung asam lemak tak jenuh rantai sedang (Medium Unmonosaturated Fatty Acid/ MUFA). Konsumsi MUFA berpengaruh positif terhadap kondisi kesehatan, termasuk mencegah penyakit kardiovaskuler dan kanker. Konsumsi olive oil dapat menurunkan konsentrasi plasma trigliserid, Very Low Density Lipoprotein (VLDL), kolesterol, dan sedikit meningkatkan HDL (Witradharma dkk., 2010). Komponen hydroxytyrosol dan polifenol pada olive oil dapat mengurangi oksidasi LDL serta aktivasi endothelium sehingga dapat mencegah pembentukan aterosklerosis (Santiago et al., 2005).

\section{KESIMPULAN}

Keimpulan dari penelitian ini adalah pemberian Virgin Coconut Oil (VCO) dengan dosis 5 dan $10 \mathrm{~mL} / \mathrm{kg}$ pakan berpotensi menyebabkan kerusakan glomerulus ginjal. Pemberian olive oil dengan dosis 5 dan $10 \mathrm{~mL} / \mathrm{kg}$ pakan lebih

aman digunakan dibanding dengan penggunaan VCO dengan dosis yang sama.

\section{DAFTAR PUSTAKA}

Covas, M. I., V. R. Gutierrez., K. Anthony., R. M. L. Raventos., O. Jesus., R. W. Owen and V. Francesco. 2006. Minor component of olive oil:

Evidence to date of health benefit to human. Nutrition 64:20-30.

Edahwati, L. 2011. Aplikasi Penggunaan Enzim Papain dan Bromelin terhadap Perolehan $V C O$. Jawa Timur : UPN-Press. (Hal 2)

Eghziaber, F.G., M. A. Pascaline., L. Koppe., C.C. Pelletier., E. Kalbacher., F. Denis and C.O. Soulage. 2013. Ectopic lipid accumulation: A potential cause for metabolic disturbances and a contributor to the alteration of kidney function. Biochemical 95: 1971-1979.

Firmansyah, M. A. 2013. Diagnosis dan tata laksana nefrosklerosis hipertensi.CDK-201. Vol.40: 107-111.

Fogo, Agnes B. 2000. Glomerular hypertension, abnormal glomerular growth, and progression of renal disease. Kidney international Vol. 57: 15-21.

Guyton, A.C and J. E. Hall. 2007. Buku Ajar Fisiologi Kedokteran. EGC. Jakarta.

Isdadiyanto, S. 2015. Efek Chitosan pada Histopatologis Aorta Tikus Putih yang Diberi Makan Lemak Tinggi. Buletin Anatomi dan Fisiologi. Vol. 13 No. 1. 57-68.

Junqueira L.C., J. Carneiro and R.O. Kelley. 2007. Histologi Dasar. Edisi ke-5 Tambayang J., penerjemah. Terjemahan dari Basic Histology. EGC. Jakarta. 
Kamariah, L., A. Azmi., A. Rosmawati., M. G..W. Ching., M. D. Azlina., Sivapragasam., C. P. Tan and O. P. Lan. 2008. Physico-chemical and quality characteristics of virgin coconut oil - A Malaysian survey. Trop. Agric. and Fd.Sc. 36(2):000-000.

Kano Y. O., T. Kawada., T. Watanabe., F. Koyama., K. Watanebe., R. Senbongi and K. Iwai. 2007. Extra virgin olive oil increases uncoupling protein 1 content in brown adipose tissue and enhances noradrenaline and adrenaline secretions in rats. Nutritional Biochemistry 18: 685-692.

Kim, H.J., J. Yuan., N. Keith and N. D. Vaziri. 2009. High-calorie diet partially ameliorates dysregulation of intrarenal lipid metabolism in remnant kidney. Nutritional Biochemistry 21: 999-1007.

Ramirez, M.C. 2006. Olive Oil and Health. CAB International.

Santiago, M. G., E. M. Bautista., J. J. Carrero., J. Fonolla., L. Baro., M. V. Bartolome., P.G. Lovzaga and E. L. Huertas. 2005. Onemonth administration of hydroxytyrosol, a phenolic antioxidant present in olive oil, to hyperlipemic rabbits improves blood lipid profile, antioxidant status and reduces atherosclerosis development. $J$. Atherosclerosis 188: 35-42.

Santoso, S. 2010. Statistik Multivariat. PT Gramedia. Jakarta.
Smith., M. S. 1998. Pemeliharaan Pembiakan dan Penggunaan Hewan Percobaan di Daerah Tropis. Edisi 1. UI Press. Jakarta.

Suhita, Ni Luh. P. R., W. Sudira., I. B. Winaya dan Oka. 2013. Histopatologi Ginjal Tikus Putih Akibat Pemberian Ekstrak Pegagan (Centella asiatica) Peroral. Buletin Veteriner Udayana. Vol. 5 No. 2.

Tambunan, S., E. Asni., Z. Malik dan Ismawati. 2014. Histopatologi Aorta Torasika Tikus Putih (Rattus norvegicus strain Wistar) Jantan Setelah Pemberian Diet Aterogenik Selama 12 Minggu. Jom. FK, Vol. 2 No. 1.

Turgeon, Mary L. 2010. Clinical Hematology, Theory and Prosedures. Boston.

Viola, Joana and Soehnlein, Oliver. 2015. Atherosclerosis-A Matter of Unresolved Inflamation. Seminars in Immunology, 27 184-193.

Witradama, T. W., N.I. Lipoeto dan A. Asri. 2010. Pengaruh Konsumsi Berbagai Jenis Asam Lemak Terhafap Indikator Kejadian Aterogenesis pada Tikus Jantan Strain Wistar. Skripsi. Program Studi Ilmu Biomedik, Universitas Andalas. Padang.

Yanuartono. 2007. Peran Diet Tinggi Lemak dan atau Kolesterol Tinggi pada Pembentukan Plak Ateroma Aorta Tikus Putih (Sprague Dawley). Jurnal Sains Vet, Vol.25 No.1

Yuniwarti, Enny, Y. W. 2015. Kadar Trigliserid Tikus Putih setelah Pemberian Berbagai Kadar VCO dan Olive Oil. Buletin Anatomi dan Fisiologi. Vol 23, nomor 2 